\title{
Treatment of Wine Distillery Wastewater: A Review with Emphasis on Anaerobic Membrane Reactors
}

\author{
X.L. Melamane, P.J. Strong and J.E. Burgess ${ }^{*}$ \\ Department of Biochemistry, Microbiology and Biotechnology, Rhodes University, P.O. Box 94, Grahamstown 6140, South Africa
}

Submitted for publication: December 2006

Accepted for publication: April 2007

Key words: anaerobic; chemical oxygen demand; effluent; membrane; polyphenol; stillage; vinasse

\begin{abstract}
This review summarises research efforts and case studies in the treatment of wine distillery wastewaters. Experiences in treating wine distillery wastewaters can contribute to the field of oenology, as many oenologists are concerned with the selection, efficiency and economy of their wastewaters. Characteristics of wastewaters from different distilleries and various methods for treating these wastes are discussed. Wine distillery wastewaters are strongly acidic, have a high chemical oxygen demand, high polyphenol content and are highly variable. Primary attention is focused on the sustainable biological treatment of wine distillery wastewaters, mainly by energyefficient anaerobic digestion in different reactor configurations from bench to pilot and full-scale treatment. Finally, areas where further research and attention are required are identified.
\end{abstract}

\section{WASTEWATER GENERATION IN DISTILLATION INDUS- TRIES}

Wine distilleries produce large volumes of liquid waste called wine distillery wastewater (also known as stillage, distillery pot ale, distillery slops, distillery spent wash, dunder, mosto, vinasse and thin stillage), which is the aqueous by-product of the distillation of ethanol, wine and some waste biological material (Sheehan and Greenfield, 1980; Vlissidis and Zoubalis, 1993; Wilkie et al., 2000; Keyser et al., 2003). Wine production is one of the most important agricultural industries in Mediterranean countries such as Italy and Spain, and its importance to other parts of the world (e.g. Australia, Brazil, Chile, China, France, Germany, India, South Africa and the United States of America) is increasing and impacting on their economies (Jimenez and Borja, 1997; Benitez et al., 1999b; Wolmarans and De Villiers, 2002; Coetzee et al., 2004; Mendonca et al., 2004; Nataraj et al., 2006). A high volume of wastewater is produced in these industries; figures range from $2 \mathrm{~L}$ per litre of wine produced (Benitez et al., 2000; Eusébio et al., 2004) to 20 L per litre of ethanol produced (Wilkie et al., 2000). In molasses-based distilleries, 13 to $15 \mathrm{~L}$ of wastewater is generated for every $1 \mathrm{~L}$ of ethanol produced (Ruiz et al., 2002). The seasonal nature of distillery industries raises specific problems for the treatment processes in terms of wine distillery wastewater volume and composition (Coetzee et al., 2004; Eusébio et al., 2004). As a result, treatment plants must be versatile in relation to the loading regimen and must be able to cope with successions of start-ups and closedowns, and even intervals of inactivity (Sales et al., 1987; Borja et al., 1993). Environmental pollution due to the release of natural polyphenolic compounds from agro-industrial operations has become widespread globally (Benitez et al., 1999b). The structure of the polyphenols that are present is similar in many industrial wastewaters, like those produced in wine distilling, olive oil extraction, green olive debittering, cork preparation, wood debarking and coffee production (Field and Lettinga, 1991; Borja et al., 1993; Brand et al., 2000; Lesage-Meessen et al., 2001; Minhalma and De Pinho, 2001; Aggelis et al., 2003; Mendonca et al., 2004).

Waste minimisation is an important aspect to any industry, as it not only reduces the consumption of potable water but also decreases the volume of wastewater generated. During the production of wine from grapes, large quantities of liquid effluent are generated from various units of operation and processes. Musee et al. (2006) designed a system that identified waste waste-generating mechanisms, analysed the causes, and then derived options for feasible waste minimisation alternatives. Musee et al. (2007) identified 90 waste minimisation strategies, which could yield considerable benefits to the wine industry if incorporated as an integral part of the entire vinification process. Waste minimisation can prove deleterious to biological treatment systems, however, as it can lead to more concentrated wastewater.

\section{WASTEWATER CHARACTERISTICS}

Table 1 lists the characteristics of different distillery wastewaters from all over the world. Parameters such as the $\mathrm{pH}$, alkalinity, electrical conductivity (EC), total chemical oxygen demand $\left(\mathrm{COD}_{\mathrm{T}}\right)$, soluble chemical oxygen demand $\left(\mathrm{COD}_{\mathrm{S}}\right)$, five-day biochemical oxygen demand $\left(\mathrm{BOD}_{5}\right)$, total organic carbon (TOC), phenol, volatile fatty acids (VFAs), volatile solids (VS), volatile suspended solids (VSS), total solids (TS), total suspended solids (TSS), mixed solids (MS), mixed suspended solids (MSS), total nitrogen (TN), ammonia $\left(\mathrm{NH}_{4}^{+}\right)$, nitrates $\left(\mathrm{NO}_{3}^{-}\right)$, total phosphorus (TP) and phosphates $\left(\mathrm{PO}_{4}^{-}\right)$are reported. In general, distillery

*Corresponding author: e-mail address: j.burgess@ru.ac.za, Fax: +27-46-622 3984

Acknowledgements: The authors would like to thank the Joint Research Committee of Rhodes University for financial support. XLM is indebted to the National Research Foundation (NRF) and Department of Labour (DoL) for Scarce Skills and The German Academic Exchange Service (DAAD) for in-country doctoral scholarships. PJS gratefully acknowledges an NRF/DoL Scarce Skills Doctoral Fellowship. Opinions stated and conclusions reached are to be attributed to the authors and are not those of the NRF or DoL. 
TABLE 1

Chemical characteristics of distillery wastewaters.

\begin{tabular}{|c|c|c|c|c|c|c|}
\hline \multirow{2}{*}{ Parameter } & \multicolumn{6}{|c|}{ Type of wastewater } \\
\hline & $\begin{array}{c}\text { Distillery } \\
\text { wastewater }\end{array}$ & $\mathrm{WDW}^{* 2}$ & Vinasse $^{3}$ & $\begin{array}{c}\text { Raw spent } \\
\text { wash }^{4}\end{array}$ & $\begin{array}{c}\text { Molasses } \\
\text { wastewater }^{5}\end{array}$ & $\begin{array}{c}\text { Lees } \\
\text { stillage }^{6}\end{array}$ \\
\hline $\mathrm{pH}$ & $3.0-4.1$ & $3.53-5.4$ & 4.4 & 4.2 & 5.2 & 3.8 \\
\hline Alkalinity (meq/l) & - & $30.8-62.4$ & - & 2 & 6000 & 9.86 \\
\hline $\mathrm{EC}$ & 346 & - & - & 2530 & - & - \\
\hline Phenol (mg/l) & - & $29-474$ & 477 & - & 450 & - \\
\hline VFA (g/l) & 1.6 & $1.01-6$ & - & - & 8.5 & 0.248 \\
\hline $\mathrm{COD}_{\mathrm{T}}(\mathrm{g} / \mathrm{l})$ & $100-120$ & $3.1-40$ & - & 37.5 & 80.5 & - \\
\hline $\mathrm{COD}_{\mathrm{S}}(\mathrm{mg} / \mathrm{l})$ & - & $7.6-16$ & 97.5 & - & - & - \\
\hline $\mathrm{BOD}_{5}(\mathrm{mg} / \mathrm{l})$ & 30 & $0.21-8.0$ & 42.23 & - & - & 20 \\
\hline TOC (mg/l) & - & $2.5-6.0$ & 36.28 & - & - & - \\
\hline VS (g/l) & 50 & $7.340-25.4$ & - & - & 79 & - \\
\hline VSS (g/l) & 2.8 & $1.2-2.8$ & - & - & 2.5 & 0.086 \\
\hline TS $(g / l)$ & $51.5-100$ & $11.4-32$ & 3.9 & 2.82 & 109 & 68 \\
\hline TSS (g/l) & - & $2.4-5.0$ & - & - & - & - \\
\hline MS (g/l) & - & 6.6 & - & - & 30 & - \\
\hline MSS (mg/l) & - & 900 & 100 & - & 1100 & - \\
\hline $\mathrm{TN}(\mathrm{g} / \mathrm{l})$ & - & $0.1-64$ & - & 2.02 & 1.8 & 1.53 \\
\hline $\mathrm{NH}_{4}{ }^{+}(\mathrm{mg} / \mathrm{l})$ & - & 140 & - & 125400 & - & 45.1 \\
\hline $\mathrm{NO}_{3}{ }^{-}(\mathrm{mg} / \mathrm{l})$ & 4900 & - & - & - & - & - \\
\hline $\mathrm{TP}(\mathrm{g} / \mathrm{l})$ & - & $0.24-65.7$ & - & 0.24 & - & 4.28 \\
\hline $\mathrm{PO}_{4}{ }^{3-}(\mathrm{mg} / \mathrm{l})$ & - & $130-350$ & - & 139 & - & - \\
\hline
\end{tabular}

* Wine distillery wastewater

References:

(1) Nataraj et al., 2006; Harada et al., 1996

(2) Bustamante et al., 2005; Eusébio et al., 2004; Genovesi et al., 2000; Benitez et al., 1999b; Borja et al., 1993

(3) Martin et al., 2002

(4) Ramana et al., 2002c

(5) Jimenez and Borja 1997

(6) Tofflemire, 1972.

wastewaters are acidic, have a brown colour and have a high content of organic substances that vary according to the raw material distilled, e.g. wine type, lees, etc. (Borja et al., 1993; Vlissidis and Zoubalis, 1993; Benitez et al., 1999b; Genovesi et al., 2000; Keyser et al., 2003; Bustamante et al., 2005). The average values for COD are 7 to $40 \mathrm{~g} / \mathrm{L}$ and for $\mathrm{BOD}_{5}$ they are 5.5 to $20 \mathrm{~g} / \mathrm{L}$ (Fumi et al., 1995; Manisankar et al., 2004). In other examples, the concentration of organic substances is very high, ranging from 20 to $150 \mathrm{~g} / \mathrm{L}$ COD (Goodwin and Stuart, 1994; Wilkie et al., 2000; Goodwin et al., 2004; Martin et al., 2002; Sheridan et al., 2005; Perez et al., 2004). In studies conducted in South Africa, the COD of wine distillery wastewater ranged from 20 $\mathrm{g} / \mathrm{L}$ to $30 \mathrm{~g} / \mathrm{L}$ (Wolmarans and De Villiers, 2002), while Driessen et al. (1994) reported COD concentrations of between 22 and 48 $\mathrm{g} / \mathrm{L}$. Wine distillery wastewaters are acidic and their high organic content can cause considerable environmental pollution (Borja et al., 1993; Keyser et al., 2003). The $\mathrm{pH}$ values of wine distillery wastewaters range from 3.5 to 5.0, as shown in Table 1 (Sheehan and Greenfield, 1980; Harada et al., 1996; Benitez et al., 1999b; Genovesi et al., 2000; Rajeshwari et al., 2000; Goodwin et al., 2001; Martin et al., 2002; Wolmarans and De Villiers, 2002; Bustamante et al., 2005). In addition to COD and BOD pollution, wine distillery wastewaters contain phenolic compounds, mainly gallic acid, $p$-coumaric acid and gentisic acid, which impart high antibacterial activity (Borja et al., 1993; Seghezzo et al., 1998; Keyser et al., 2003).

Moosbrugger et al. (1993) observed that South African wine distillery wastewater consists primarily of organic acids such as lactic acid (29\% v/v), tartaric acid (27\% v/v), succinic acid $(26 \%$ $\mathrm{v} / \mathrm{v})$, acetic acid $(10 \% \mathrm{v} / \mathrm{v})$ and malic acid $(8 \% \mathrm{v} / \mathrm{v})$. In addition to these organic acids, alcohol, hexose sugars and soluble proteins have been found (Seghezzo et al., 1998; Keyser et al., 2003). Several problems have been encountered during the biological treatment of wine distillery wastewater because of high toxicity and the inhibition of biodegradation due to the presence of polyphenolic compounds (Goodwin et al., 2001), which demonstrates the antibacterial activity reported in the earlier literature (Borja et al., 1993). Polyphenol concentrations in some distillery wastewaters vary considerably and can range from 29 to $474 \mathrm{mg} / \mathrm{L}$ (Bustamante et al., 2005). Polyphenols are responsible for strong inhibitory effects on microbial activity and must be removed during wastewater treatment, owing to the environmental and public health risks they pose. Humans exposed to phenol at $1300 \mathrm{mg} / \mathrm{L}$ of concentration exhibit significant increases in diarrhoea, dark urine, mouth sores and burning of the mouth (Collins et al., 2005). Wine distillery wastewaters have also been characterised for heavy metals, viz. iron and zinc, metal ions such as $\mathrm{Ca}^{2+}, \mathrm{K}^{+}$and $\mathrm{Na}^{+}$(Harada et al., 1996; Ramana et al., 2002a; 
Nataraj et al., 2006) and sulphates (Harada et al., 1996; Ramana et al., 2002a). High concentrations of these constituents (Ramana et al., 2002a; Eusébio et al., 2004), plus other nutrients such as nitrate and phosphate, make the possible discharge of wine distillery wastewaters into water bodies problematic, as they cause eutrophication and other adverse environmental effects (Borja et al., 1993; DWAF, 1996; Collins et al., 2005).

\section{WINE DISTILLERY WASTEWATER DISPOSAL AND USE}

Three popular methods are employed by distilleries to handle their wastewaters: (1) collection of wastewater in storage tanks, followed by irrigation, (2) wastewater treatment in ponds, primarily for the settling of solids, evaporation processes and application of resultant sludge on land, and (3) discharge of the wastewater to a local municipal treatment facility (Benitez et al., 1999b). These three methods have their associated problems and environmental risks. Treatment of wine distillery wastewaters at municipal facilities is very expensive and is often not a feasible, practical or viable option. In South Africa, the Department of Water Affairs and Forestry (DWAF) began a project in 1999 to develop a waste discharge charge system (WDCS). The WDCS is being designed in order to manage wastewater and water resources efficiently and effectively (DWAF, 2003). It addresses the pricing of water used for waste disposal and proposes a system in which wastewater treatment costs are minimised when at least partial wastewater treatment occurs on the premises of the discharger, as opposed to the release of raw, untreated wastewater into the sewer or receiving environment (DWAF, 2003). Wine distillery wastewaters were thought to have some beneficial impacts on crop yields, as land application or irrigation is a common method of disposal (Mulidzi et al., 2002). The wastewater is first screened, settled in ponds and then distributed over land containing trees, grass and crops using a sprinkler system or channels (Mulidzi et al., 2002). According to DWAF (2003) analysis, winery wastewater disposal by irrigation has tremendous potential for polluting ground water and other fresh water bodies due to the presence of high concentrations of phenolic compounds, salinity, phosphates, nitrates and ammonia, which can lead to toxic effects and eutrophication. As a result, the DWAF (2003) proposed that irrigation of fields by winery wastewaters can be done only if the concentration of nutrients is within set limits. These limits were established after some researchers reported that the high salt concentrations in wine distillery wastewaters resulted in severe inhibitory effects on plants during irrigation. Investigations showed that there were differing responses to varying concentrations of wine distillery wastewater in irrigation water with regard to the percentage of seeds sown that germinated and the speed of germination (Ramana et al., 2002a). At low concentrations of wine distillery wastewater, all crops that were tested showed no inhibition of seed germination, except for tomatoes. However, the percentage germination and the germination speed were inhibited by irrigation with water containing increased concentrations of wine distillery wastewater (Ramana et al., 2002a).

The inhibitory effects of wine distillery wastewater on plant growth can be attributed to the high percentage of organic compounds and salts, and thus its high electrical conductivity, which makes water uptake by seeds difficult and causes retardation of germination (Ramana et al., 2002a). It was found that at concentrations of wine distillery wastewater $>25 \%(\mathrm{v} / \mathrm{v})$, there was sig- nificant fungal growth on the seeds, which was inhibited seed germination (Ramana et al., 2002a). Conversely, Ramana et al. (2002b) later showed an increase in the grain yield of maize, associated with larger cob sizes, higher numbers of seeds per cob and increased grain weight upon irrigation with wine distillery wastewater. It was found that the positive effect on maize crops was observed at low concentrations of wine distillery wastewater. At these low concentrations, grain yields equivalent to those achievable when using the recommended NPK+FYM (nitrogen, phosphate, potassium and farmyard manure) level of fertilisation could be obtained (Ramana et al., 2002b). The concentration of wine distillery wastewater used to irrigate maize crops could not be increased to greater than $25 \%$, as this would have resulted in problems of salinity. Instead it was recommended that a nonsaline fertiliser be used to supplement wine distillery wastewater for increased maize grain yields (Ramana et al., 2002b). A similar effect was observed for groundnut (Ramana et al., 2002c). It was concluded that soil and crop types are important when choosing to irrigate land with wine distillery wastewater, as its effect is both soil dependent and crop specific (Ramana et al., 2002c).

This was corroborated by a study of irrigation of Pennisetum clandestinum (kikuyu grass) on sandy soil. The organic components of wine distillery wastewater leached through the sandy soil and reached the groundwater table, receiving at least partial treatment on the way (Mulidzi et al., 2002). Groundwater recharge by high-rate infiltration is a common method of renewing water sources with wastewater in the arid regions of the USA, and water shortages in areas surrounding alcohol and wine distilleries in South Africa could be partially ameliorated by the reuse of treated wine distillery wastewater to replace potable water for irrigation purposes wherever possible, for example in vineyard irrigation (DWAF, 1996; Van Schoor, 2004). However, distillery wastewater disposal by irrigation could potentially cause a large-scale environmental problem to which little attention has been paid by this industry until recently (Benitez et al., 1999b; Van Schoor, 2004). One historical alternative to broad surface irrigation disposal of stillage was deep well disposal (Zajic, 1971; Sheehan and Greenfield, 1980). Even though deep well disposal is a cheaper method than land disposal, limited underground storage and very specific geological formations interfere with any widescale stillage disposal. Van Schoor (2004) summarised research advances and made recommendations on the use of wine distillery wastewater, the legal requirements in South Africa for winery wastewater irrigations and wine distillery wastewater storage. Again, ferti-irrigation and biocomposting with sugarcane press mud were also found to be popular methods for wastewater disposal (Noble and Stern, 1995). However, these methods are highly energy intensive and hence financially and environmentally expensive. These disadvantages emphasised the need for further research using novel solid/liquid separation methods. As a result, membrane-based separation techniques, such as reverse osmosis (RO) and nanofiltration (NF), were investigated and yielded excellent results when applied to wine distillery wastewater (Noble and Stern, 1995). The effectiveness of NF membrane processes in water and wastewater treatment is generally acknowledged and has now become the most reliable standard technique in combination with biological treatment (Bustamante et al., 2005; Trussell et al., 2006). Membrane-based separation 
processes like NF, ultrafiltration (UF) and RO have been applied for treating a wide variety of industrial wastewaters (Nataraj et al., 2006). As the cost of wastewater disposal increases, more emphasis is being placed on the recovery and recycling of the valuable chemicals and other components contained in these waste streams.

\section{Traditional treatment practices}

Most of the wastewaters from different distillery sources were historically discharged directly into the soil or in ground water. Reich (1945) proposed one of the first treatment systems, a continuous integrated method to concentrate the stillage by fermentation, where the fermenter discharge was centrifuged and the yeast that was not recycled was drum-dried for use as an animal feed. The stillage was concentrated to 70 to $80 \%$ solids and then neutralised with potassium carbonate $\left(\mathrm{K}_{2} \mathrm{CO}_{3}\right)$. The concentrated, neutralised wastewater was passed through low-temperature carbonising retorts and activated at $870^{\circ} \mathrm{C}$, and the resultant carbon underwent aqueous extraction to produce potash fertiliser (potassium oxide $\left(\mathrm{K}_{2} \mathrm{O}\right)$ ), potash liquor and char. A decade later, Montanani (1954) reported on the slightly more developed Tibrocal system, in which stillage was neutralised with lime (calcium oxide $(\mathrm{CaO})$ or calcium hydroxide $\left.\left(\mathrm{Ca}(\mathrm{OH})_{2}\right)\right)$ and then evaporated in $10 \mathrm{~cm}$ shallow containers, again for use as a fertiliser. Other similar schemes were proposed by Chakrabarty (1964) and Yamauchi (1977), with the difference that crystallised potassium sulphate was produced instead of potassium oxide. In Europe, distillery wastewater was incinerated, normally yielding $34.7 \%$ of potash fertiliser and $2.2 \%$ phosphorus oxide (or ceramic oxide $\left(\mathrm{P}_{2} \mathrm{O}_{5}\right)$ ) (Sastry and Mohanrao, 1964). Another method was distillery wastewater concentration to 30 to $40^{\circ} \mathrm{Brix}$, followed by spray drying and combustion at $700^{\circ} \mathrm{C}$, with the resultant ash being collected at the column base (Gupta et al., 1968). Similar methods were used with small variations, such as concentration of the stillage to $60 \%$ solids and spray drying into fuel gases (Dubey, 1974). Tartrate removal has also been used as a pre-treatment step (Tofflemire, 1972). Fluidised bed combustion of stillage, followed by heat recovery, has also been suggested (Kujala et al., 1976). However, scale formation was reported as a problem in some of the incineration and evaporation schemes, and the energy costs were prohibitive. Jackman (1977) reported on Brazilian efforts to reduce scaling and to raise the ash fusion temperature by adding other chemicals. The French practice was to concentrate the stillage to $60 \%$ solids and then use it as a fertiliser at an application rate of 2.5 to 3.0 tonnes per hectare (Lewiki, 1977). Monteiro (1975) considered this method uneconomical in the Brazilian context. The extraction of specific chemicals from wine distillery wastewater for sale as by-products has been conducted to offset the costs of wastewater treatment and to improve subsequent treatment and disposal (Zabrodiskli et al., 1970). Gypsum $\left(\mathrm{CaSO}_{4} \cdot 2 \mathrm{H}_{2} \mathrm{O}\right)$ was recovered by the addition of seed crystals to the stillage at $80^{\circ} \mathrm{C}$ and stirring at 22 to $25 \mathrm{rpm}$ for 60 minutes. This alleviated the problem of gypsum precipitation in cases where stillage was to be used for fodder yeast growth. Potassium and its double salt $\left(\mathrm{K}_{2} \mathrm{SO}_{4} \cdot 5 \mathrm{CaSO}_{4} \cdot \mathrm{H}_{2} \mathrm{O}\right)$ can also be removed from wastewater concentrated to 30 to $60^{\circ} \mathrm{Brix}$ (Juslingha, 1970). Bass (1974) found that stillage concentrated to 60 to $80^{\circ}$ Brix formed coagulate when soluble phosphate was added and the temperature was increased to 105 to $120^{\circ} \mathrm{C}$. The coagulate was then dried further and used as a fertiliser or ruminant fodder. Dubey (1974) stated that glycerol and germ oil were other chemicals that could be recovered from distillery wastewaters, but, even as late as 1980, distillery wastewater or stillage was still usually just evaporated to provide animal feed or fertiliser, or incinerated for the possible recovery of the potash (Sheehan and Greenfield, 1980).

\section{Current treatment and disposal options}

More recent wine distillery wastewater treatment includes methods to remove recalcitrant compounds by physicochemical processes using distillery wastewater and biologically-treated distillery wastewater (Pandey et al., 2003). In one case example, the physicochemical treatment of biologically-treated wastewater using conventional coagulant iron pickling wastewater supplemented with coagulant aid generated an effluent with COD in the range 940 to $1780 \mathrm{mg} / \mathrm{L}$ and a BOD of 25 to $30 \mathrm{mg} / \mathrm{L}$. During this study, the colour of the treated wastewater was in the range of 580 to 1100 platinum cobalt units. It was recommended that the waste sludge from this industry be utilised as a substitute for conventional coagulants. Wastewater generated after chemical coagulation could be further treated efficiently by using $8 \mathrm{~g} / \mathrm{L}$ of activated carbon with a contact time of $45 \mathrm{~min}$ to reduce residual COD to $<250 \mathrm{mg} / \mathrm{L}$ to meet discharge limits (Pandey et al., 2003). Anodised graphite anodes were found to be suitable for the treatment of wine distillery wastewater, especially in the presence of supporting electrolytes such as sodium halide, or sodium chloride, which was found to be the most effective in the degradation of polyphenols (Manisankar et al., 2004). Beltran de Heredia et al. (2005) later evaluated a combination of the Fenton coagulation/flocculation process (using $\mathrm{H}_{2} \mathrm{O}_{2} / \mathrm{Fe}^{2+}$ ) for the treatment of wine distillery wastewaters and obtained a $74 \%$ reduction in COD under optimised conditions. The worldwide scarcity of water is a strong incentive for recovering clean water for reuse from wastewaters. Nataraj et al. (2006) investigated the treatment of distillery spent wash by removing the colour and the contaminants using a combination of NF and RO processes. Due to the high fluxes obtained, significant rejection rates of total dissolved solids (TDS), COD, potassium and chloride concentrations were achieved. The absence of heat energy requirements in this application and the high rate of mass transfer generated by RO showed that a large amount of clean water could be permeated economically instead of being vaporised by energy-intensive evaporation processes or steam distillation using tall towers. Water reclaimed by NF and RO is suitable for use in both municipal and industrial applications.

Chemical oxygen demand was considerably reduced in distillery wastewaters in India in order to reduce the cost of wastewater disposal. This process emphasised the recovery and recycling of valuable chemicals contained in the wastewaters (Nataraj et al., 2006). Some methods of treatment of wine distillery wastewater result in single cell production, the production of organic acids for sale in the industrial market, and the production of viable biological products, including enzymes, astaxanthia, plant hormones and biopolymers such as chitosan (Wilkie et al., 2000). Glycerol recovery, first suggested in 1974, was finally achieved towards the end of the 20th century by concentrating wastewater to $60 \%$ solids, followed by the addition of quicklime (calcium oxide $(\mathrm{CaO})$ ) and ethanol, which led to the precipitation of $90 \%$ 
of the glycerol that was present. Germ oil was obtained by heating distillery wastewater, centrifuging at $6000 \mathrm{~g}$ and extracting the oil solvent from the lightest fraction. As with the generation of fertiliser for direct land application, the economics of any treatment method rely heavily on the financial value that can be assigned to the resultant product. The pre-treatment of wine distillery wastewater with ozone improves its kinetic behaviour during anaerobic digestion, but at the same time decreases COD removal efficiencies (Benitez et al., 1999a; Martin et al., 2002).

Martin et al. (2002) investigated the ozonation of vinasse in trying to reduce COD. Vinasse is known to be chemically very complex because of the high content of polyphenols, which delay biological processes such as anaerobic digestion. As a result, ozonation is seen as a desirable chemical pre-treatment prior to biological treatment because it is capable of converting the inhibitory and refractory compounds into simpler, low molecular weight compounds that are more readily degradable by microorganisms. Ozonation of aromatic compounds usually increases their biodegradability. However, in many cases the chemical pre-treatment used to make the waste biodegradable diminishes the COD of the wastewater, although intermediate compounds of higher microbial toxicity can be generated, depending on the type of ozonation used as pre-treatment (Martin et al., 2002). In such cases, an alternative chemical oxidant has been used, and the treatment of wine distillery wastewater in a continuous reactor using a combination of ozonation and aerobic degradation in activated sludge systems has also been investigated (Benitez et al., 2000). In this combined system, oxidation by ozone achieved a reduction in the organic substrate concentration of 4.4 to $18 \%$, while removal of the content of phenol compounds in the range of 50 to $60 \%$ was achieved. Aerobic degradation of these vinasses by activated sludge in experiments using varying hydraulic retention time (HRT) and substrate concentration provided organic substrate removal in the range of 12 to $60 \%$ (Benitez et al., 2000). Ozonation of this aerobically pre-treated vinasse led to an increase in COD removal efficiency from 16 to $21.5 \%$, as well as higher rate constants (Benitez et al., 2000). Schäfer et al. (2001) later applied membrane filtration with concomitant chemical treatment in the management of wastewaters containing natural organic problems. COD removal efficiencies were improved in aerobically pre-treated and then ozonated wastewaters (Benitez et al., 1999a). Later, Benitez et al. (2000) pre-treated wine distillery wastewater with activated sludge and then ozonated it, which improved substrate removal. The COD removal efficiencies were decreased in the presence of ozone, UV light or titanium dioxide, but methane yield increased (Martin et al., 2002).

\section{Biological treatment}

Tofflemire (1972) named pre-treatment as the usual practice in nearly all major systems for treating wastewaters long before preozonation of wine distillery wastewater began. On-site modifications, such as water conservation, are performed for the essential reduction of waste and removal of solids. Relatively easy solid/liquid separation is desirable, because it reduces the volumetric load on the wastewater treatment system. Solid residues such as stems, pomace and lees can be removed from wastewaters by filtration, sedimentation, cycloning or screening. Solids have been disposed of by burying, spreading on fields or use as cattle feed. Neutralisation by mixing wastewaters with each other or by base addition is still practised. Non-chemical pre-treatment of wine distillery wastewater includes mechanical processes such as steam explosion (Wilkie at al., 2000), supercritical explosion by $\mathrm{CO}_{2}$, ammonia freeze explosion, solvent delignification using alcohols, and thermal mechanical processes to improve microbial access to the substrate (Zheng et al., 1998). All these methods can be used to improve subsequent biological treatment. Pre-treatment was also recently investigated by Nataraj et al. (2006), who worked with wine distillery wastewater with a $\mathrm{pH}$ of around 3. The wastewater was pre-treated by neutralisation with sodium hydroxide $(\mathrm{NaOH})$, and filtration was carried out to remove the high concentrations of suspended solids before using the wine distillery wastewater as secondary influent (Nataraj et al., 2006). For the biological treatment of wine distillery wastewater, aerobic systems such as aerated lagoons or activated sludge plants are commonly used to remove the COD (Benitez et al., 1999a). However, aerobic processes have high operating costs and generate large quantities of waste sludge, which need to be disposed of (Benitez et al., 1999a).

Combining distillery wastewaters with municipal or other wastewater may allow the toxic components to be diluted and facilitate treatment. Jackson et al. (2007) used a bioreactor system to treat mixed metal-contaminated river water and distillery wastewater with a two-week HRT. The aluminium concentration decreased from $0.75 \mathrm{mg} / \mathrm{L}$ to $0.18 \mathrm{mg} / \mathrm{L}$ and nickel was completely removed (originally $0.19 \mathrm{mg} / \mathrm{L}$ ), while the COD of the distillery wastewater was decreased from $2255 \mathrm{mg} / \mathrm{L}$ to a final value of $<150 \mathrm{mg} / \mathrm{L}$.

In studies conducted by Benitez et al. (1999a), purification of wine distillery wastewater by combined processes, consisting of aerobic degradation followed by anaerobic digestion, was performed with the aim of evaluating the influence of the first stage, considered as a pre-treatment, on the performance of the second stage. The pre-treatment of the wine distillery wastewater by means of an aerobic process led to a significant increase in the methane yield of the following, anaerobic stage. The results of this research indicate that single aerobic treatment achieves an important reduction of the substrate $( \pm 90 \%)$ and significant removal of the total phenolic compounds (66 to 79\%). However, biological wastewater treatment processes, such as activated sludge and aerated ponds, have been dogged by operational problems when treating high organic load wastewaters such as wine distillery wastewater (Vlissidis and Zoubalis, 1993). These aerobic treatment systems are used mainly to remove the BOD of these wastes. Partial reduction of BOD and COD is achieved in many distilleries using biological treatment (Jawed and Tare, 1999; Laubscher et al., 2001; Wolmarans and De Villiers, 2002; Coetzee et al., 2004).

Hybrid biological treatment systems include anaerobic treatment with the recovery of biogas, followed by aerobic treatment for the removal of residual BOD and COD. However, most of the biologically-treated distillery wastewaters are dark brown in colour and contain a high COD due to the presence of recalcitrant compounds such as caramel, melanoids, a variety of sugar decomposition products, anthocyanins and tannins, and other xenobiotic compounds formed during yeast growth and the processing of alcohols (Benitez et al., 1999b). The biological treatment of industrial wastewaters usually depends on the oxidative activities of 
microorganisms, and most bacteria are not able to degrade the recalcitrant xenobiotics mentioned above. Filamentous fungi can be important sources of phenolic-degrading organisms, as they frequently grow on wood, utilising lignin as a carbon source (Benitez at al., 1999b; Coulibaly et al., 2003; Mendonca et al., 2004). Fungi are not frequently used in wastewater treatment, as they are difficult to cultivate in liquid media and their rate of growth is slow in comparison to most microbial species (Coulibaly et al., 2003; Mendonca et al., 2004). However, organic compounds like phenol and its derivatives have antibacterial effects that limit bacterial treatment, because they can be growth limiting even to species that have the metabolic ability to use phenolic compounds as substrates. Fungi have shown potential for the treatment of various specific pollutants and mixed wastewaters, including dark-coloured, phenolic wastewaters such as molasses (Jimenez et al., 2003) and olive mill waste (Perez et al., 1998; Ruiz et al., 2002; Aggelis et al., 2003; Fenice et al., 2003; Mendonca et al., 2004), which means that fungal treatment of these wastewaters could be used as a pre-treatment step for anaerobic digestion. According to Coulibaly et al. (2003), fungi can be used to treat wastewaters in a liquid environment, where bioreactors with wastewater can be exposed to the specific live fungus that is capable of degrading a single pollutant, or preferably a mixture of pollutants. Another approach would be to use an enzyme derived from fungi to treat the wastewater (Coulibaly et al., 2003).

There has been considerable global scientific effort to research the use of fungi in bioremediation, especially the lignin-degrading white-rot fungi for the degradation of wastes with phenolic content (Fernando et al., 1990). Phanerochaete chrysosporium, a white-rot fungus producing peroxidases, is exceptionally versatile in degrading wastewaters containing phenolic compounds (Bumpus and Aust, 1987; Coulibaly et al., 2003). Fungal pre-treatment of wastewaters that exert some antibacterial activity under aerobic conditions has resulted in complete phenol and colour removal and BOD reductions of up to $85.4 \%$ (Coulibaly et al., 2003). Aerobic pre-treatment of molasses with Penicillium decumbens enhanced the rate of subsequent anaerobic degradation, and the kinetic coefficients doubled (Jimenez and Borja, 1997). Successful biodegradation of natural phenolic compounds, such as phenol, catechol and resorcinol, prepared at concentrations of up to $1 \mathrm{~g} / \mathrm{L}$, was achieved in the presence of a filamentous fungus called Fusarium flocciferum (Mendonca et al., 2004). However, the search for sustainable treatment systems capable of minimising energy consumption has encouraged the use of anaerobic bacterial systems, even in cases where the main goal is to eliminate the biodegradable and dissolved fraction of carbonaceous substrates (Rajeshwari et al., 2000). These anaerobic treatment systems have been used mainly for high-strength organic wastewaters such as beer-brewing wastewaters (Sales et al., 1987; Benitez et al., 1999b). Although anaerobic digestion of this wine distillery wastewater is feasible and appealing from an energy point of view, the presence of polyphenols slows down the digestion process and thus hinders COD removal. An improvement in digestion efficiency can be brought about by modifying the digester design, incorporating appropriate advanced operating techniques (Rajeshwari et al., 2000) or using more robust microorganisms. Table 2 provides a summary of different digester configurations used for the anaerobic digestion of distillery wastewaters. Anaerobic digestion offers significant advantages over aerobic systems, including lower energy consumption, reduced solids formation, lower nutrient requirements and potential energy recovery from the methane produced (Hall, 1992; Steward et al., 1995; Garcia-Calderon et al., 1998). This process is now widely used in many environmental applications, in different reactor configurations and different modes of operation (Borja et al., 1993; Goodwin et al., 2001; Wolmarans and De Villiers, 2002; Coetzee et al., 2004). Genovesi et al. (2000) claimed that, in the past few decades, biological treatment processes, and anaerobic digestion in particular, have been proven effective and economical in dealing with highly polluted wastewaters. Several technologies are applied for winery wastewater treatment, including free cells or flocs (anaerobic contact digesters, anaerobic sequencing batch reactors and anaerobic lagoons), anaerobic granules (Upflow Anaerobic Sludge Blanket), or biofilms on fixed support (anaerobic filter) or on mobile support, as in the fluidised bed (Moletta, 2005). Anaerobic digestion is able to operate under severe conditions, i.e. high-strength influents and short hydraulic retention times. It is a process often used as a treatment for the stabilisation of primary and secondary sludges. Anaerobic digestion of high-strength wastewater is a proven technology that has been widely applied (Rajeshwari et al., 2000; Wolmarans and De Villiers, 2002). The removal of COD using anaerobic digestion for winery and distilleries wastewaters (vinasses) is very high, up to $95 \%$, with organic loads between 5 and $15 \mathrm{~kg} \mathrm{COD} / \mathrm{m}^{3}$ of digester/day. The biogas production is between 400 and $600 \mathrm{~L}$ per $\mathrm{kg}$ COD removed and contains between 60 and $70 \%$ methane (Moletta, 2005). However, a major concern is that digestion systems often do not perform well, as long start-up periods in the order of one to two months have been reported (Austermann-Haunn et al., 1994), which is a major barrier to the use of such systems for seasonal wine distillery wastewater streams. García-Bernet et al. (1998) studied a down-flow anaerobic fluidised bed treating red wine distillery wastewater over 1.5 years on laboratory scale. The system attained carbonremoval efficiency rates of between 75 and $95 \%$, at an organic loading rate (OLR) of $17 \mathrm{~kg}$ TOC $/ \mathrm{m}^{3} /$ day, with an HRT of 0.35 days. However, it required a two-month start-up period, with stepwise increases in OLR that were achieved by reducing the HRT. Hickey et al. (1991) suggested that, when a reactor for a particular wastewater is commissioned for the first time, it is advantageous to utilise sludge from a reactor treating a similar waste as the commissioning inoculum. If this is not possible, the sludge will have to be acclimatised to the specific influent, a process that can take several weeks or months. Several processes have thus been developed to operate anaerobic digestion reactors, each of them having several advantages. One of the most common is the upflow anaerobic sludge blanket (UASB), a process that has successfully been used to treat a variety of wastewaters, but is often limited by poor biodegradability of complex organic substrates (Goodwin and Stuart, 1994; Seghezzo et al., 1998; Goodwin et al., 2001; Wolmarans and De Villiers, 2002; Coetzee et al., 2004). Keyser et al. (2003) improved the performance of a UASB during the treatment of winery wastewater by adding granular sludge enriched with Enterobacter sakazaki to the reactor. The enriched bioreactor led to better wastewater treatment performance, as the reactor start-up time was reduced and COD removal of $>90 \%$ was achieved. 
TABLE 2

Performance levels of anaerobic digestion of wine distillery wastewaters.

\begin{tabular}{|c|c|c|c|c|c|c|c|}
\hline Reactor type & HRT & $\begin{array}{c}\text { Organic } \\
\text { loading rate }\end{array}$ & $\begin{array}{l}\text { Temp. } \\
\left({ }^{\circ} \mathrm{C}\right)\end{array}$ & $\begin{array}{l}\text { COD removal } \\
\text { efficiency }(\%)\end{array}$ & Waste type & Application & References \\
\hline $\begin{array}{l}\text { Anaerobic } \\
\text { digester }\end{array}$ & $3 \mathrm{~d}$ & - & 35 & - & Vinasse & Laboratory scale & Martin et al. (2002) \\
\hline $\begin{array}{l}\text { Anaerobic filter } \\
\text { and UASB }\end{array}$ & $1.3 \mathrm{~d}$ & $\begin{array}{l}3.0-5.4 \mathrm{~kg} \\
\mathrm{COD} / \mathrm{m}^{3} / \mathrm{d}\end{array}$ & 37.5 & 90 & $\begin{array}{l}\text { Distillery } \\
\text { wastewater }\end{array}$ & Laboratory scale & Blonskaja et al. (2003) \\
\hline $\begin{array}{l}\text { Anaerobic granular } \\
\text { sludge reactor }\end{array}$ & $24 \mathrm{~h}$ & $\begin{array}{c}10.0 \mathrm{~kg} \\
\mathrm{COD} / \mathrm{m}^{3} / \mathrm{d}\end{array}$ & $15.0-18.0$ & $80-90$ & $\begin{array}{l}\text { Phenolic } \\
\text { wastewater }\end{array}$ & Laboratory scale & Collins et al. (2005) \\
\hline $\begin{array}{l}\text { Anaerobic up-flow } \\
\text { fixed bed }\end{array}$ & - & $\begin{array}{c}0.2-18.0 \mathrm{~kg} \\
\mathrm{COD} / \mathrm{m}^{3} / \mathrm{d}\end{array}$ & 36 & - & $\begin{array}{l}\text { Winery } \\
\text { wastewater }\end{array}$ & Pilot scale & Genovesi et al. (2000) \\
\hline $\begin{array}{l}\text { Down flow } \\
\text { fluidized bed }\end{array}$ & $1.3 \mathrm{~d}$ & $\begin{array}{c}1.8-4.5 \mathrm{~kg} \\
\mathrm{TOC} / \mathrm{m}^{3} / \mathrm{d}\end{array}$ & 35 & $>95$ & $\begin{array}{l}\text { Wine distillery } \\
\text { wastewater }\end{array}$ & Laboratory scale & Garcia-Calderon et al. (1998) \\
\hline Flasks & $1.7-4.0 \mathrm{~d}$ & $3.79 \mathrm{~g} / \mathrm{l} / \mathrm{d}$ COD & 55 & 78.9 & Vinasse & Laboratory scale & Solera et al. (2002) \\
\hline $\begin{array}{l}\text { Stirred anaerobic } \\
\text { digester }\end{array}$ & $3.1-15.4 \mathrm{~d}$ & $\begin{array}{l}0.55-0.75 \mathrm{~g} \\
\mathrm{COD} / \mathrm{gVSS} / \mathrm{d}\end{array}$ & - & - & $\begin{array}{l}\text { Molasses } \\
\text { wastewater }\end{array}$ & Laboratory scale & Jimenez and Borja (1997) \\
\hline UASB & $2.1 \mathrm{~d}$ & $\begin{array}{c}5.46-20.0 \mathrm{~kg} \\
\mathrm{COD} / \mathrm{m}^{3} / \mathrm{d}\end{array}$ & Mesophilic & $70-90$ & $\begin{array}{l}\text { Distillery } \\
\text { pot ale }\end{array}$ & Laboratory scale & Goodwin et al. (2001) \\
\hline UASB & - & $\begin{array}{c}0.46-0.75 \mathrm{~kg} \\
\mathrm{COD} / \mathrm{kgVS}\end{array}$ & 35 & 90 & $\begin{array}{l}\text { Distillery } \\
\text { pot ale }\end{array}$ & Laboratory scale & Goodwin and Stuart (1994) \\
\hline UASB & - & $\begin{array}{c}2.0-18.0 \mathrm{~kg} \\
\mathrm{COD} / \mathrm{m}^{3} / \mathrm{d}\end{array}$ & $34-36$ & 90 & $\begin{array}{l}\text { Distillery } \\
\text { wastewater }\end{array}$ & Full scale & Wolmarans and De Villiers (2002) \\
\hline UASB & $48 \mathrm{~h}$ & $\begin{array}{c}6.1-18.0 \mathrm{~kg} \\
\mathrm{COD} / \mathrm{m}^{3} / \mathrm{d}\end{array}$ & 35 & $>90$ & $\begin{array}{l}\text { Grain } \\
\text { distillation } \\
\text { wastewater }\end{array}$ & Laboratory scale & Laubscher et al. (2001) \\
\hline UASB & - & $\begin{array}{c}19.0-24.0 \mathrm{~kg} \\
\mathrm{COD} / \mathrm{m} 3 / \mathrm{d}\end{array}$ & $60-65$ & $>95$ & $\begin{array}{l}\text { Recalcitrant } \\
\text { distillery } \\
\text { wastewater }\end{array}$ & Laboratory scale & Harada et al. (1996) \\
\hline UASB & $2.2 \mathrm{~d}$ & $\begin{array}{c}5.1-10.12 \mathrm{~kg} \\
\mathrm{COD} / \mathrm{m}^{3} / \mathrm{d}\end{array}$ & 35 & 90 & $\begin{array}{l}\text { Winery } \\
\text { wastewater }\end{array}$ & Laboratory scale & Keyser et al. (2003) \\
\hline
\end{tabular}

\section{Membrane bioreactors in the treatment of distillery waste- waters}

A membrane bioreactor (MBR) can be defined as a process that integrates the biological degradation of wastewater when coupled with membrane filtration (Cicek et al., 2001). The combination of membranes in the biological treatment of wastewaters was first reported by Smith et al. (1969). In that study, a UF membrane was used for the separation of activated sludge from the final effluent, with recycling of the biomass to the aeration tank (Smith et al., 1969). This led to the development of three generic membrane processes. The first is the solid - liquid membrane separation process, which employs ultra/micro-filtration modules for the retention of biomass for recycling to the bioreactor. Secondly, gaspermeable membranes can be used to provide diffused oxygen mass transfer to the degradative bacteria present in the bioreactor. This same membrane can act as support for biofilm development, with direct oxygen transfer through the membrane wall in one direction and nutrient diffusion from the bulk liquid phase into the biofilm in the other direction (Brindle and Stephenson, 1996). The third MBR is an extractive membrane that was designed for the transfer of degradable organic pollutants from industrial waste- waters, via a non-porous silicone membrane, to a nutrient medium for subsequent degradation (Schoerberl et al., 2005). These three MBRs are not mutually exclusive and, if necessary, can be coupled in one bioreactor (Brindle and Stephenson, 1996). In addition, micro- and ultra-filtration membranes allow for the separation of the activated sludge (biomass) from the treated wastewater, which offers the advantage of complete removal of solids and bacteria, as well as of most of the viruses, and allows a much higher biomass concentration (Cornel and Krause, 2006).

The coupling of a membrane to a digester offers several advantages over conventional biological wastewater treatment systems, which employ gravity for separation of the solids from the effluent (Visvanathan et al., 2000). These advantages include better biomass retention, higher organic loading rates, high-quality effluent, compact plant configuration, complete removal of solids, a disinfection capability and removal of nitrates. This makes MBRs attractive for water reclamation and meeting stringent effluent discharge requirements (Fan et al., 2000; Schoeberl et al., 2005). Membrane bioreactor systems are therefore increasingly applied to industrial wastewater treatment (Cicek et al., 2001; Enegess et al., 2003; Schoeberl et al., 2005). In solid-liq- 
uid separations, the membrane can be external to the bioreactor and can be operated under pressure (called an external membrane bioreactor (EMBR), as illustrated in Figure 1A); or submerged in the bioreactor and operated under a vacuum (a submerged membrane bioreactor (SMBR), as shown in Figure 1B) (Stephenson et al., 2000; Trussell et al., 2006). In EMBRs, the mixed liquor is pumped from the aeration tank to the membrane, at flow rates that are 20 to 30 times the product water flow, to provide adequate shear for controlling solids accumulation at the membrane surface (Trussell et al., 2006).

Submerged membrane bioreactor systems have an advantage over EMBR, as the higher cost of pumping makes EMBR systems impractical for full-scale wastewater treatment works, which do not generate any financially valuable by-products (Gander et al., 2000). Another advantage of SMBRs in wastewater treatment is the long sludge retention time (SRT) that can be achieved (Haung et al., 2001). This leads to increased concentrations of mixed liquor suspended solids (MLSS), the ability to treat wastewaters with high organic loads, and the selective development of biomass with the ability to efficiently eliminate specific wastewater components. In SMBR systems, the wastewater is driven through the membrane, using a static head of mixed liquor or a low vacuum, and the solids are left behind (Gander et al., 2000; Stephenson et al., 2000; Trussell et al., 2006). The principal process limitation of SMBRs is membrane fouling, i.e. a decrease in membrane permeability with time during system operation. Membrane fouling can be minimised by bubble aeration, backflushing, or by operating SMBRs with 10 to $20 \mathrm{~g} / \mathrm{L}$ of MLSS to maintain membrane permeability (Côte et al., 1998; Mourato et al., 1999; Trussell et al., 2000). Trussell et al. (2000) maintain that, regardless of operating conditions, SMBR effluents generated after treatment contain undetectable concentrations of TSS below $2 \mathrm{mg} / \mathrm{L}$ and a COD of between 20 and $30 \mathrm{mg} / \mathrm{L}$ because of the filtration provided by the membrane. Since the 1980s, MBR technology has been successfully applied to a range of industrial wastewaters, including oily wastewater (Knoblock et al., 1994), food wastewater (Mallon et al., 1999), tannery wastewaters (Yamamoto and Win, 1991) and landfill leachates (Mirsha et al., 1996). In South Africa, MBR technology has been applied in the treatment of maize wastewater (Ross et al., 1992) and brewery wastewater (Strohwald and Ross, 1992). However, a study of the molecular-weight distribution of compounds in the supernatant inside an SMBR and in its permeate, found that most of the permeate components had molecular weights of $<30 \mathrm{KDa}$. This portion constituted 60 to $70 \%$ of the material, while 10 to $20 \%$ originated from compounds with molecular weights of $>100 \mathrm{KDa}$. The relative proportion of the high molecular-weight fraction in the permeate increased with operation time (Haung et al., 2001). Ultra-filtration and micro-filtration (MF) membranes can prevent the loss of biological solids and high molecular-weight solutes from the bioreactor. Complete mineralisation of the organic matter is facilitated by maintaining a high biomass concentration and retaining high molecular-weight compounds (Brindle and Stephenson, 1996). As a result of membrane separation, SRT is independent of HRT, although the SRT and HRT are not without influence on process performance.

Ren et al. (2005) investigated the impact of changing HRT on the removal of organic pollutants from domestic sewage by SMBRs in the laboratory. The results demonstrated that when the
HRT was 3, 2 and $1 \mathrm{~h}$, COD removal efficiency was 89.3 to $97.2 \%, 88.5$ to $97.3 \%$, and 80 to $91.1 \%$ respectively. The results also showed that the optimum MLSS had to be maintained at $6000 \mathrm{mg} / \mathrm{L}$. Membrane bioreactors are most attractive for situations where a long SRT is necessary to achieve the removal of slowly-degradable pollutants. Due to the high biomass concentrations that can be maintained in MBRs, a minimum amount of maintenance energy is required for biosynthesis and cell growth (Brindle and Stephenson, 1996). Maintaining a low feed to microorganism $(\mathrm{F} / \mathrm{M})$ ratio in MBRs results in minimum sludge generation, reduced footprint and the development and retention of microorganisms that are wastewater specific.

At steady state, MBRs can remove organic pollutants over a wide range of concentrations, producing a high-quality permeate at high organic loading rates (Brindle and Stephenson, 1996). These loading rates range from $0.2 \mathrm{~kg} \mathrm{COD} / \mathrm{m}^{3} / \mathrm{d}$ in aerobic MBRs, i.e. loading rates that are similar to conventional activated sludge, to $19.7 \mathrm{~kg} \mathrm{COD} / \mathrm{m}^{3} /$ day in anaerobic MBRs (Brindle and Stephenson, 1996). The removal efficiency of organic compounds is generally greater than $90 \%$, although COD removal efficiencies of as low as $61 \%$ have been reported. Aerobic MBRs have been investigated in the treatment of municipal and inorganic industrial wastewaters. Knoblock et al. (1994) demonstrated that aerobic MBRs operated at $54.2 \mathrm{~h}$ HRT and an organic loading rate of 6.3 $\mathrm{kg} \mathrm{COD} / \mathrm{m}^{3} / \mathrm{d}$ were capable of treating high-strength metalworking wastewaters and achieved $94.4 \%$ COD removal. In addition to a reduction in oxygen demand, significant removal of ammonia, fats, oils, greases and phosphorous have been confirmed. Brindle and Stephenson (1996) investigated the effect of organic loading rates on membrane fouling in an aerobic SMBR treating municipal wastewater. The study was carried out for 415 days on a pilot scale. Steady-state fouling rates were determined for 10, 5, 4, 3 and 2 days SRT, and these corresponded to F/M ratios of 0.34 , $0.55,0.73,0.84$ and $1.41 \mathrm{~g} \mathrm{COD/g} \mathrm{VSS/day} \mathrm{respectively.} \mathrm{It} \mathrm{was}$ found that membrane fouling increased as the $\mathrm{F} / \mathrm{M}$ ratio was increased and that carbohydrate soluble microbial products (SMP) were responsible for increased fouling rates at high loading rates. Yamada et al. (2006) achieved $>80 \%$ COD removal in a pilotscale multi-staged thermophilic $\left(55^{\circ} \mathrm{C}\right)$ UASB reactor with a working volume of $2.5 \mathrm{~m}^{3}$, operated for a period of over 600 days using alcohol distillery wastewater. What was exceptional was the organic loading rate of $60 \mathrm{~kg} \mathrm{COD} / \mathrm{m}^{3} / \mathrm{day}$. From their studies, it was concluded that the propionate degradation step was the most critical bottleneck regarding the overall anaerobic degradation of organic matter under thermophilic conditions.

Synthetic wastewater was treated with an SMBR to investigate the organic removal performance and behaviour of SMP during long-term operation (Haung et al., 2000). The removal efficiency of the chemical oxygen demand was $90 \%$, while the removal efficiencies of TOC and BOD were $94 \%$ and $95 \%$ respectively. The accumulation of TOC with a molecular weight of $>100 \mathrm{KDa}$ was $34 \%$. This accumulation proved to be inhibitory towards the metabolic activity of activated sludge, which decreased from 34 to $16 \%$, while TOC of molecular weight $<30 \mathrm{KDa}$ increased from 33 to 52\% (Haung et al., 2000). Trussell et al. (2006) demonstrated that slow-growing nitrifying bacteria were retained in an MBR at organic loading rates of 0.9 to $2.0 \mathrm{~kg} \mathrm{COD} / \mathrm{m}^{3} / \mathrm{day}$. The system could maintain $100 \%$ nitrification and $90 \%$ COD removal efficien- 


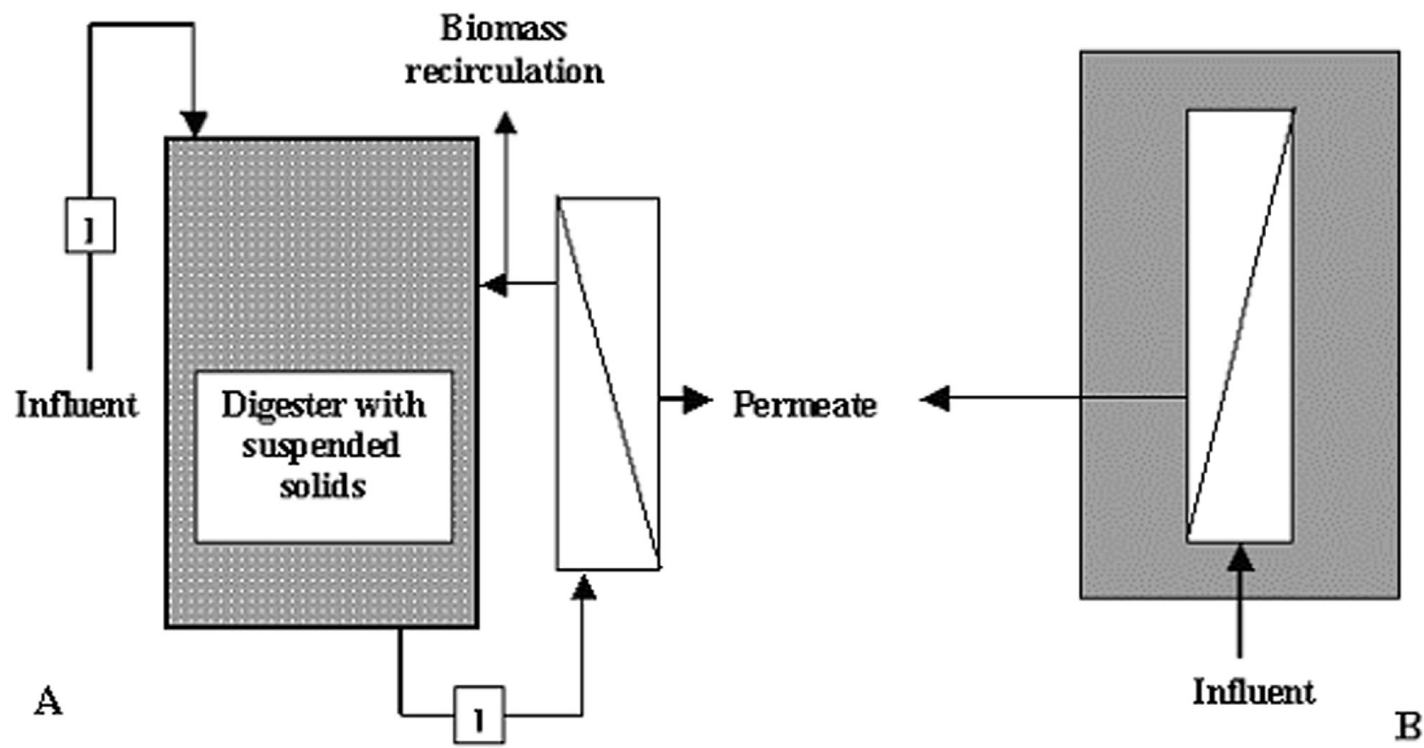

FIGURE 1

Example of (A) an external membrane bioreactor (EMBR) and (B) a submerged membrane bioreactor (SMBR).

cy for 300 days' SRT and 7.4 to 50.0 hours' HRT. Organic removal and complete nitrification were achieved even at HRTs as low as two hours. A membrane biological reactor (Zenon ZW-10) with a volume of $220 \mathrm{~L}$ was used for 50 days to treat a synthetic wastewater similar to that generated in wineries. Removal efficiency of the chemical oxygen demand above $97 \%$ was obtained, and the COD concentration in the permeate varied from 60 to $80 \mathrm{mg} / \mathrm{L}$. Biomass concentration, in terms of volatile suspended solids, ranged between 0.5 and $15 \mathrm{~g} \mathrm{VSS} / \mathrm{L}$ and the apparent biomass yield was estimated at $0.14 \mathrm{~g} \mathrm{VSS} / \mathrm{g}$ COD (Artiga et al., 2005).

One of the earliest applications of MBRs in the treatment of wine industry wastewater was the use of an EMBR to treat Shochu distillery wastewater containing high-strength organic compounds and ultra-high-strength suspended solids (Nagano et al., 1992). A pilot-scale EMBR was operated for 190 days with an UF membrane unit of $12 \mathrm{~m}^{2}$, an operating pressure of 1.5 $\mathrm{kg} / \mathrm{cm}^{2}$, polysulphone membranes with a molecular weight cutoff of $2000 \mathrm{KDa}$, an operating temperature of $37^{\circ} \mathrm{C}$ and an MCRT of infinity (no sludge removal). This MBR was capable of achieving 98\% COD and 99\% BOD removal efficiencies (Nagano et al., 1992). Suspended solids were decomposed at a high ratio of $85 \%$, with little excess sludge discharged from the MBR. The conversion rate was $0.057 \mathrm{~kg}-\mathrm{VSS} / \mathrm{kg}$-feed COD and the methane production rate was from 0.28 to $0.34 \mathrm{~m}^{3} / \mathrm{kg}$-feed COD (Nagano et al., 1992). Recently, Zhang et al. (2006) monitored the performance of a metallic SMBR treating simulated distillery wastewater at temperatures of 30 to $45^{\circ} \mathrm{C}$. A stainless steel membrane with $0.2 \mathrm{~mm}$ pore size was used to treat this wastewater, with a COD concentration of about $1 \mathrm{~g} / \mathrm{L}$. The results obtained showed that the ability of sludge to settle became poorer with increasing temperature. The mean COD and TN removal efficiencies at 10 to $30 \mathrm{~h} \mathrm{HRT}$ and a volumetric loading rate (VLR) of 0.6 to $2.8 \mathrm{~kg} \mathrm{COD} / \mathrm{m}^{3} / \mathrm{h}$ were $94.7 \%$ and $84.4 \%$ respectively (Zhang et al., 2006), figures which concurred in earlier work and support the idea that MBRs could be much more widely used in the wine and associated distillery industrial sectors.

\section{CONCLUSION}

Although the wide variations in the composition of distillery wastewaters make them extremely difficult to bioremediate, successful biological treatment of these wastewaters has been reported. This suggests that novel methods of treatment, or the improvement of established methods, could be successful, despite changes in wastewater volume and composition. In the evaluation and reporting of any treatment process, sufficient detail about the characteristics and concentrations of species present in the distillery wastewaters must be provided, along with the treatment performance in order for judgement to be made in respect of the application of the treatment process to other wastewaters. However, this information is not readily available in public literature, as the chemical characteristics of distillery wastewaters are often not reported, except for COD, $\mathrm{pH}, \mathrm{VFA}$, and sometimes BOD, TN and TP (see Table 1). There is a lack of consistency in the characterisation of distillery wastewaters, as parameters such as phenols/polyphenols, alkalinity, EC, VS, VSS, TS, TSS, $\mathrm{NO}_{3}^{-}$, $\mathrm{NH}_{4}{ }^{+}, \mathrm{PO}_{4}{ }^{3-}$ are sometimes omitted. Harada et al. (1996) were the only researchers to include parameters such as $\mathrm{SO}_{4}{ }^{2-}, \mathrm{K}^{+}, \mathrm{Na}^{+}$, $\mathrm{Fe}^{3+}, \mathrm{Zn}^{3+}$ and $\mathrm{Ca}^{2+}$ in their publications. This lack of information has been a trend, despite the inhibitory characteristics of phenols, $\mathrm{SO}_{4}{ }^{2-}$, metal ions and heavy metals, even at low concentrations. Regulatory bodies such as the DWAF have minimum requirements for the concentrations of these species that must be met before effluent is reused or disposed of (DWAF, 1996). It therefore is recommended that local studies are necessary in order to comply with standards of effluent disposal. The pre-treatment of wine distillery wastewaters by either the removal of solids, neutralisation with alkali or the dilution of wastewater before treatment is often necessary. A number of unsuccessful digester trials also sug- 
gest that high organic loading rates adversely affect digester performance. At bioreactor configuration level, the existing information can thus be used to further improve performance. At the same time, the key question is still related to the role of inorganic ions in biological treatment processes. The removal efficiencies of polyphenols, $\mathrm{NO}_{3}{ }^{-}, \mathrm{NH}_{4}{ }^{+}$and $\mathrm{PO}_{4}{ }^{3-}$ also need to be profiled as indicators of performance in digesters. Membrane bioreactors used in the treatment of wine distillery wastewaters show potential, but little recent research is easily accessible. At the same time, amelioration of membrane fouling does not appear to pose a major problem, and because of increasing energy and wastewater disposal costs the most attractive treatment processes for wine distillery wastewaters are those with the lowest operational and maintenance, rather than capital, costs.

\section{LITERATURE CITED}

Aggelis, G., Iconomou, D., Christou, M., Bokas, D., Kotzaillias, S., Christou, G., Tsagou, V. \& Papanikolaou, S., 2003. Phenolic removal in a model olive mill wastewater using Pleurotus ostreatus in bioreactor cultures and biological evaluation of the process. Water Res. 37, 3897-3904.

Artiga, P., Ficara, E., Malpei, F., Garrido, J.M. \& Méndez, R., 2005. Treatment of two industrial wastewaters in a submerged membrane bioreactor. Desalination $179,161-169$.

Austermann-Haun, U., Seyfried, C.F., Kunst, S., Brockmann, M., Banzinger, W. \& Rosenwinkel, K.H., 1994. Anaerobic pretreatment in campaign industries. In: Proc. 7th Int. Symp. on Anaerobic Digestion, Cape Town, South Africa. pp. 325 - 336.

Bass, H.H., 1974. Preparation of fertilizer and animal feed from molasses fermentation residue. United States Patent 3983255.

Beltran de Heredia, J., Dominguez, J.R. \& Partido, E., 2005. Physico-chemical treatment for the depuration of wine distillery wastewaters (vinasses). Water Sci. Technol. 51(1), 159-166

Benitez, F.J., Beltran-Heredia, J., Real, F.J. \& Acero, J.L., 1999a. Enhancement of the ozonation of wine distillery wastewaters by an aerobic pretreatment. Bioprocess Eng. 21, 459-464.

Benitez, F.J., Beltran-Heredia, J., Real, F.J. \& Acero, J.L., 2000. Wine vinasses treatments by ozone and an activated sludge system in continuous reactors. Bioprocess Eng. 23, 149-154

Benitez, F.J., Beltran-Heredia, J., Real, F.J. \& Gonzalez, T., 1999b. Aerobic and anaerobic purification of wine distillery wastewater in batch reactors. Chem. Eng. Technol. 22, 165-172.

Blonskaja, V., Menert, A. \& Vilu, R., 2003. Use of two-stage anaerobic treatment for distillery waste. Advances Environ. Res. 7, 671-678.

Borja, R., Martin, A., Maestro, R., Luque., M. \& Durán, J., 1993. Enhancement of the anaerobic digestion of wine distillery wastewater by the removal of phenolic inhibitors. Bioresour. Technol. 45, 99-104.

Brand, D., Pandey, A., Rouss, S. \& Soccol, C.R., 2000. Biological detoxification of coffee husk by filamentous fungi using a solid state fermentation system. Enzyme Microb. Technol. 27(1-2), 127-133.

Brindle, K. \& Stephenson, T., 1996. The application of membrane biological reactors for the treatment of wastewaters. Biotechnol. Bioeng. 49, 601-610.

Bumpus, J.A. \& Aust, S.D., 1987. Biodegradation of DDT [1,1,1-trichloro-2,2bis(chlorophenyl)ethane] by the white-rot fungus Phanerochaete chrysosporium. Appl. Environ. Microbiol. 53, 2001-2008.

Bustamante, M.A., Paredes, C., Moral, R., Moreno-Casalles, J., Pérez-Espinosa, A. \& Pérez-Murcia, M.D., 2005. Uses of winery and distillery effluents in agriculture: Characterization of nutrient and hazardous components. Water Sci. Technol. 51(1), 145-151.

Chakrabarty, R.N., 1964. Potash recovery - a method of disposal of distillery wastes and saving foreign exchange. In: Proc. Symp. on Ethyl Alcohol Production Techniques, New Delhi, India. pp. 93 - 97.

Cicek, N., Macomber, J., Davel, J., Suidan, M.T., Audic, J. \& Genestet, P., 2001. Effect of solids retention time on the performance and biological characteristics of a membrane bioreactor. Water Sci. Technol. 43(11), 43-50.
Coetzee, G., Malandra, L., Wolfaardt, G.M. \& Viljoen-Bloom, M., 2004. Dynamics of microbial biofilm in a rotating biological contactor for the treatment of winery effluent. Water SA 30(3), 407-412.

Collins, G., Foy, C., McHugh, S., Maho, T. \& O’Flaherty, V., 2005. Anaerobic biological treatment of phenolic wastewater at $15-18^{\circ} \mathrm{C}$. Water Res. 39, 1614-1620.

Cornel, P. \& Krause, S., 2006. Membrane bioreactors in industrial wastewater treatment - European experiences, examples and trends. Water Sci. Technol. 53(3), 7-44.

Côte, P., Buisson, H. \& Praderie, M., 1998. Immersed membranes activated sludge process applied to the treatment of municipal wastewater. Water Sci. Technol. 38(4-5), 437-442.

Coulibaly, L., Gourene, G. \& Agathos, N.S., 2003. Utilization of fungi for biotreatment of raw wastewaters. African J. Biotechnol. 12, 620-630.

Driessen, W.J.M.B., Tielbaard, M.H. \& Vereijken, T.L.F.M., 1994. Experience on anaerobic treatment of distillery effluent with the UASB process. Water Sci. Technol. 30(12), 193-201.

Dubey, R.S., 1974. Distillery effluents - treatments and disposal. Sugar News Annual 6, 9-26.

DWAF (Department of Water Affairs and Forestry), 1996 (2nd ed). South African water quality guidelines, Volume 4, Agricultural use: Irrigation. Pretoria. pp. 121 -130 .

DWAF (Department of Water Affairs and Forestry), 2003 (1st ed). Towards a strategy for a waste discharge charge system. Water Quality Management Series: SubSeries No. MS11. Pretoria. pp. $10-22$

Enegess, D., Togna, A.P. \& Sutton, P.M., 2003. Membrane separation applications to biosystems for wastewater treatment. Filtr. Separat. 40(1), 14-17.

Eusébio, A., Petruccioli, M., Lageiro, M., Federici, F. \& Duarte, J.C., 2004. Microbial characterization of activated sludge in jet-loop bioreactors treating winery wastewaters. J. Ind. Micr. Biotechnol. 31(1), 29-34.

Fan, X.J., Urbain, V., Qian, Y., Manem, J., Ng, W.J. \& Ong, S.L., 2000. Nitrification in a membrane bioreactor (MBR) for wastewater treatment. Water Sci. Technol. 42(3-4), 289-294.

Fenice, M., Sermani, G.G., Federici, F. \& D’Annibale, A., 2003. Submerged and solid-state production of laccase and Mn-peroxidase by Panus tigrinus on olive mill wastewater-based media. J. Biotechnol. 100, 77-85.

Fernando, T., Bumpus, J.A. \& Aust, S.D., 1990. Bioremediation of TNT (2,4,6trinitrotoulene) by Phanerochaete chrysosporium. Appl. Environ. Microbiol. 56, 1666-1671.

Field, J.A. \& Lettinga, G., 1991. Treatment and detoxification of aqueous spruce bark extracts by Aspergillus niger. Water Sci. Technol. 24(3-4), 127-137.

Fumi, M. D., Parodi, G., Parodi, E. \& Silva, A., 1995. Optimization of long-term activated sludge treatment of winery wastewater. Bioresour. Technol. 52, 45-51.

Gander, M., Jefferson, B. \& Judd, S., 2000. Aerobic MBRs for domestic wastewater treatment; a review with cost consideration. Sep. Purif. Technol. 18, 119130 .

García-Bernet, D., Buffière, P., Elmaleh, S. \& Moletta, R., 1998. Application of the down-flow fluidized bed to the anaerobic treatment of wine distillery wastewater. Water Sci. Technol. 38(8-9), 393-399.

Garcia-Calderon, D., Buffiere, P., Moletta, R. \& Elmaleh, S., 1998. Anaerobic digestion of wine distillery wastewater in down-flow fluidized bed. Water Res. $32(12), 3593-3600$

Genovesi, A., Harmand, J. \& Steyer, J-P., 2000. Integrated fault detection and isolation: Application to a winery's wastewater treatment plant. Appied. Intell. 13, 59-76.

Goodwin, J.A.S. \& Stuart, J.B., 1994. Anaerobic digestion of malt whisky distillery pot ale using upflow anaerobic sludge blanket reactors. Bioresour. Technol. $49,75-81$.

Goodwin, J.A.S., Finlayson, J.M. \& Low, E.W., 2001. A further study of the anaerobic biotreatment of malt whisky distillery pot ale using an UASB system. Bioresour. Technol. 78, 155-160.

Gupta, S.C., Shukla, J.P. \& Shukla, N.P., 1968. Recovery of crude potassium salts from spent wash of molasses distilleries by fluidized incineration. In: Proc. 36th Ann. Conv. Sugar Technologies Assoc., XXXXIII-1-XXXXIII-7. Cited in: Nandy, T., Shastry, S. \& Kaul, S.N., 2002. Wastewater management in a cane molasses distillery involving bioresource recovery. J. Env. Manag. 65(1), 25-38. 
Hall, E., 1992. Anaerobic treatment of wastewaters in suspended growth and fixed film processes. In: Malina, J. \& Pohland, F. (eds). Design of Anaerobic Processes for the Treatment of Industrial and Municipal Wastes. CRC Press Ltd., Lancaster, PA, USA. pp. $41-118$.

Harada, H., Uemura, S., Chen, A.C. \& Jayadevan, J., 1996. Anaerobic treatment of a recalcitrant distillery wastewater by a thermophilic UASB reactor. Bioresour. Technol. 55, 215-221.

Hickey, R.F., Wu, W.-M., Viega, M.C. \& Jones, R., 1991. Start-up, operation, monitoring and control of high-rate anaerobic treatment systems. Water Sci. Technol. 24(8), 207-255.

Huang, X., Gui, P. \& Qian, Y., 2001. Effect of sludge retention time on microbial behaviour in a submerged membrane bioreactor. Process Biochem. 36, 1001-1006.

Huang, X., Liu, R. \& Qian, Y., 2000. Behaviour of soluble microbial products in a membrane bioreactor. Process Biochem. 36, 401-406.

Jackman, E.A., 1977. Distillery effluent treatment in the Brazilian National Alcohol Programme. Chem. Eng. 319, 239-242.

Jackson, V.A., Paulse, A.N., Bester, A.A., Neethling, J.H., Du Plessis, K.R. \& Khan, W., 2007. The application of bioremediation: Reduction of metal concentrations in river water and COD in distillery effluent. Water Sci. Technol. 55(3), $183-186$.

Jawed, M. \& Tare, V., 1999. Microbial composition assessment of anaerobic biomass through methanogenic activity tests. Water SA 25(3), 345-350.

Jimenez, A.M. \& Borja, R. 1997. Influence of aerobic pretreatment with Penicillium decumbens on the anaerobic digestion of beet molasses alcoholic fermentation wastewater in suspended and immobilized cell bioreactors. J. Chem. Technol. Biotechnol. 69, 193-202.

Jimenez, A.M., Rafael, B. \& Martin, A., 2003. Aerobic-anaerobic biodegradation of beet molasses alcoholic fermentation wastewater. Process Biochem. 38, 12751284.

Juslingha van, J. (Invr.) N.V. Centrale Suiker Maatshapij, 1970. Process for removing potassium from molasses or vinasse in the form of its double salt $\mathrm{K}_{2} \mathrm{SO}_{4} \cdot \mathrm{CaSO}_{4} \cdot 1 \mathrm{H}_{2} \mathrm{O}$. German OLS 1817550 .

Keyser, M., Witthuhn, R.C., Ronquest, L.C. \& Britz, T.J., 2003. Treatment of winery effluent with upflow anaerobic sludge blanket (UASB) - granular sludges enriched with Enterobacter sakazakii. Biotechnol. Letters 25(22), 1893-1898.

Knoblock, M.D., Sutton, P.M., Mirsha, P.N., Gupta, K. \& Janson, A., 1994. Membrane biological reactor system for treatment of oily wastewater. Water Environ. Res. 66, 133-139.

Kujala, P., Hull, R., Engstrom, F. \& Jackman, E., 1976. Alcohol from molasses as a possible fuel and the economics of distillery effluent treatment. Sugar y Azucar 29, 32-39.

Laubscher, A.C.J., Wentzel, M.C., Le Roux, J.M.W. \& Ekama, G.A., 2001. Treatment of grain distillation wastewater in an upflow anaerobic sludge bed (UASB) system. Water SA 27(4), 433-444.

Lesage-Messen, L., Navarro, D., Maunier, S., Sigoillot, J-C., Lorquin, J., Delattre, M., Simon, J.-L., Asther, M., \& Labat, M., 2001. Simple phenolic content in oil residues as a function of extraction systems. Food Chem. 75(4), 501-507.

Lewiki, W., 1977. Introduction to the technology, application and marketing of concentrated vinasses from the molasses fermentation industry. Z. Zuckerindustrie 27, 302-303.

Mallon, D., Steen, F., Brindle, K. \& Judd, S., 1999. Performance on a real industrial effluent using a Zenogem MBR. In: Stephenson, T. (ed). Proc. 2nd Int. Meeting on Membrane Bioreactors for Wastewaters for Wastewater Treatment, June 1999, Cranfield, UK. pp. 1 - 7.

Manisankar, P., Rani, C. \& Viwanathan, S., 2004. Effects of halides in the electrochemical treatment of distillery effluent. Chemosphere 57, 961-966.

Martin, M.A., Raposo, F., Borja, R. \& Martin, A., 2002. Kinetic study of the anaerobic digestion of vinasse pretreated with ozone, ozone plus ultraviolet, and ozone plus ultraviolet light in the presence of titanium dioxide. Process Biochem. 37, 699-706.

Mendonca, E., Martins, A. \& Anselmo, A.M., 2004. Biodegradation of natural phenolic compounds as single and mixed substrates by Fusarium flocciferum. Electr. J. Biotechnol. 7(1), 30-36.

Minhalma, M. \& De Pinho, M., 2001. Tannic membrane interactions on ultrafiltration of cork processing wastewaters. Separ. Purif. Technol. 22, 479-488.
Mirsha, P.N., Sutton, P.M. \& Mourato, D., 1996. Industrial wastewater biotreatment optimization through membrane applications. In: Proc. 89th Meeting Air and Waste Manag. Assoc., June 1996, Nashville, Tennessee, USA.

Moletta, R., 2005. Winery and distillery wastewater treatment by anaerobic digestion. Water Sci. Technol. 51(1), 137-144.

Montanani, F.N., 1954. Ingenieria Sanitaria 8, 21-43.

Monteiro, C.E., 1975. Brazilian experience with the disposal of waste water from the cane sugar and alcohol industry. Process Biochem. November, 33-41.

Moosbrugger, R.E., Wentzel, M.C., Ekama, G.A. \& Marais, G.R., 1993. Treatment of wine distillery waste in UASB systems - feasibility, alkalinity requirements and $\mathrm{pH}$ control. Water Sci. Technol. 28(2), 45-54.

Mourato, D., Thompson, D., Schneider, C., Wright, N., Devol, M. \& Rogers, S., 1999. Upgrade of a sequential batch reactor into a ZenoGem. In: WEFTEC® 1999: 72nd Annual Water Environment Federation Technical Exhibition and Conference, October 1999, New Orleans, LA, USA. Water Environment Federation, Alexandria VA. [CD-ROM].

Mulidzi, R., Laker, G., Van Schoor, L. \& Louw, K., 2002. Fate of organic components of winery effluents in soils. WineLand South Africa 5, 82-83.

Musee, N., Lorenzen, L. \& Aldrich, C., 2006. Decision support for waste minimization in wine-making processes. Environ. Prog. 25 (1): 56-63.

Musee, N., Lorenzen, L. \& Aldrich, C., 2007. Cellar waste minimization in the wine industry: a systems approach. J. Cleaner Prod. 15, 417-431.

Nagano, A., Arikawa, E. \& Kobayashi, H., 1992. The treatment of liquor wastewater containing high-strength suspended solids by membrane bioreactor system. Water Sci. Technol. 26(3-4), 887-895.

Nataraj, S.K., Hosamani, K.M. \& Aminabhavi, T.M., 2006. Distillery wastewater treatment by the membrane based nanofiltration and reverse osmosis. Water Res. 40, 2349-2356.

Noble, R.D. \& Stern, S.A., 1995. Membrane Separation Technology: Principles and Applications. Elsevier, Amsterdam.

Pandey, R.A., Malhotra, S., Tankhiwale, A., Pande, S., Pathe, P.P. \& Kaul, S.N., 2003. Treatment of biological treated distillery effluent - a case study. Internat. J. Environ. Studies 60, 263-275.

Perez, M., Romero, L.I. \& Sales, D., 1998. Comparative performance of high rate anaerobic thermophilic technologies treating industrial wastewater. Water Res. 32, $559-564$

Rajeshwari, K.V., Balakrishnan, M., Kansal, A., Lata, K. \& Kishore, V.V.N., 2000. State-of-the-art of anaerobic digestion technology for industrial wastewater treatment. Ren. Sus. Energy Reviews 4, 135-156.

Ramana, S., Biswas, A.K. \& Singh, A.B., 2002b. Short communication: Effect of distillery effluent on some physiological aspects in maize. Bioresour. Technol. 84, 294-297.

Ramana, S., Biswas, A.K., Kundu, S., Saha, J.K. \& Yadava, R.B.R., 2002a. Effect of distillery effluent on seed germination in some vegetable crops. Bioresour. Technol. 82, 273-275.

Ramana, S., Biswas, A.K., Kundu, S., Saha, J.K. \& Yadava, R.B.R., 2002c. Relative efficacy of different distillery effluents on growth, nitrogen fixation and yield of groundnut. Bioresour. Technol. 81, 117-121.

Reich, G.T., 1945. Production of carbon and potash from molasses distiller's stillage. Trans. Amer. Inst. Chem. Eng. 41, 233-251.

Ren, N., Chen, Z., Wang, A. \& Hu, D., 2005. Removal of organic pollutants and analysis of MLSS-COD removal at different HRTs in a submerged membrane bioreactor. International Biodeterior. Biodegrad. 55, 279-284.

Ross, W.R, Banard, J.P., Strohwald, K., Grobler, C.J. \& Sanetra, J., 1992. Practical application of the ADUF process to the full scale treatment of a maize-processing effluent. Water Sci. Technol. 25(10), 27-39.

Ruiz, G, Jeison, D. \& Chamy, R., 2006. Development of denitrifying and methanogenic activities in USB reactors for the treatment of wastewater: Effect of COD/N ratio. Process Biochem. 41, 1338-1342.

Sales, D., Valcarcel, M.J., Perez, L. \& Martinez-Ossa, E., 1987. Activated sludge treatment of wine-distillery wastewaters, J. Chem. Technol. Biotechnol. 40, 8599.

Sastry, C.A. \& Mohanrao, G.J., 1964. Treatment and disposal of distillery wastes. Chem. Age. India 15, 88-96. 
Schäfer, A.I., Fane, A.G. \& Waite, T.D., 2001. Cost factors and chemical pretreatment effects in the membrane filtration of waters containing natural organic matter. Water Res. 35(6), 1509-1517.

Schoeberl, P., Brik, M., Bertoni, M., Braun, R. \& Fuchs, W., 2005. Optimization of operational parameters for a submerged membrane bioreactor treating dyehouse wastewater. Sep. Purif. Technol. 44, 61-68.

Seghezzo, L., Zeeman, G., Van Lier, J.B., Hamelers, H.V.M. \& Lettinga G., 1998. A review: The anaerobic treatment of sewage in UASB and SGSB reactors. Bioresour. Technol. 65, 175-190.

Sheehan, G. J. \& Greenfield, P.F., 1980. Utilization, treatment and disposal of distillery wastewater. Water Res. 14, 257-277.

Sheridan, C.M., Bauer, F.F., Burton, S. \& Lorenzen, L., 2005. A critical process analysis of wine production to improve cost, quality and environmental performance. Water Sci. Technol. 51(1), 39-46.

Smith, C.W., Di Gregorio, D. \& Talcott, R.M., 1969. The use of ultrafiltration membrane for activated sludge separation. In: Proc. 24th Ann. Purdue Industrial Waste Conf., June 1969, Purdue University, West Lafayette, Indiana, USA. pp. $1300-1310$

Solera, R., Romera, L.I. \& Sales, D., 2002. The evolution of biomass in a twophase anaerobic treatment process during start-up. Chem. Biochem. Eng. 16(1), $25-29$

Stephenson, T., Brindle, K., Judd, S. \& Jefferson, B., 2000. Membrane Bioreactors for Wastewater Treatment. IWA Publishing, London.

Steward, J.M., Bhattacharya, S.K., Madura, R.L., Mason, S.H. \& Schonberg, J.C., 1995. Anaerobic treatability of selected organic toxicants in petrochemical wastes. Water Res. 29, 2730-2738.

Strohwald, N.K. \& Ross, W.R., 1992. Application of the ADUF process to brewery effluent on a laboratory scale. Water Sci. Technol. 25(10), 95-105.

Tofflemire, T.J., 1972. Survey of methods of treating wine and grape wastewater. Amer. J. En. Vit. 23(4), 165-172.

Trussell, R.S., Adham, S., Gagliardo, P., Merlo, R. \& Trussell, R.R., 2000. WERF: Application of membrane bioreactor (MBR) technology for wastewater treatment. In: Proc. WEFTEC® 2000: 73rd Ann. Water Env. Fed. Tech. Exhibit. Conf.,
October 2000, Anaheim, CA, USA. Water Environment Federation, Alexandria, VA [CD-ROM]

Trussell, R.S., Merlo, R.P., Hermanowicz, S.W. \& Jenkins, D., 2006. The effect of organic loading on process performance and membrane fouling in a submerged membrane bioreactor treating municipal wastewater. Water Res. 40, 2675-2683.

Van Schoor, L.H., 2004. A prototype ISO 14001 environmental management system for wine cellars. Dissertation, Stellenbosch University, Private Bag X1, 7602 Matieland (Stellenbosch), South Africa.

Visvanathan, C., Ben Aim, R. \& Parameshwaran, K., 2000. Membrane separation bioreactors for wastewater treatment. Rev. Environ. Sci. Technol. 30(1), 1-48.

Vlissidis, A. \& Zouboulis, A.J., 1993. Thermophilic anaerobic digestion of alcohol distillery wastewaters. Bioresour. Technol. 43, 131-140.

Wilkie, A.C., Riedesel, K.J. \& Owens, J.M., 2000. Stillage characterization and anaerobic treatment of ethanol stillage from conventional and cellulosic feedstocks. Biomass Bioenergy 19, 63-102.

Wolmarans, B. \& De Villiers, G., 2002. Start up of a UASB effluent treatment plant on distillery wastewater. Water SA 28(1), 63-68.

Yamada, M., Yamauchi, M., Suzuki, T., Ohashi, A. \& Harada, H., 2006. On-site treatment of high-strength alcohol distillery wastewater by a pilot-scale thermophilic multi-staged UASB (MS-UASB) reactor. Water Sci. Technol. 53(3), 27-35.

Yamamoto, K. \& Win, K.M., 1991. Tannery wastewater treatment using sequencing batch membrane reactor. Water Sci. Technol. 23(7-9), 1639-1648.

Yamauchi, T., 1977. Wastewater treatment in fermentation. Japan Kokai 77, 365-372.

Zabrodskii, A.G., Parkhomchuk, M.A. \& Soshko, G.F., 1970. Precipitation of gypsum from molasses distillery residues prior to incubation of food yeasts. Ferment. Spirit Prom. 35, 17-19.

Zajic, J.E., 1971. Water Pollution Disposal and Reuse. Marcel Dekker, New York.

Zhang, S., Yang, F., Liu, Y., Zhang, X., Yamada, Y. \& Furukawa, K., 2006. Performance of a metallic membrane bioreactor treating simulated distillery wastewater at temperature of 30 to $45^{\circ} \mathrm{C}$. Desalination $194,146-155$.

Zheng, Y., Lin M.H. \& Tsao G.T., 1998. Pretreatment of cellulose hydrolysis by carbon dioxide explosion. Biotechnol. Prog. 14(6), 890-896. 